\title{
Increased susceptibility of white spot syndrome virus-infected Litopenaeus vannamei to Vibrio campbellii
}

L. H. Phuoc, ${ }^{1}$ M. Corteel, ${ }^{2}$ H. J. Nauwynck, ${ }^{2}$

M. B. Pensaert, ${ }^{2}$ V. Alday-Sanz,${ }^{3}$ W. Van den Broeck, ${ }^{4}$

P. Sorgeloos ${ }^{1}$ and P. Bossier ${ }^{1 *}$

${ }^{1}$ Laboratory of Aquaculture \& Artemia Reference Center, Faculty of Bioscience Engineering, Ghent University,

Rozier 44, B-9000 Ghent, Belgium.

${ }^{2}$ Laboratory of Virology and ${ }^{4}$ Laboratory of Morphology, Faculty of Veterinary Medicine, Ghent University, Salisburylaan 133, 9820 Merelbeke, Belgium.

${ }^{3}$ Aquatic Animal Health, Portal del Angel, 3-5, 2, 08002

Barcelona, Spain.

\section{Summary}

The concept of polymicrobial disease is well accepted in human and veterinary medicine but has received very little attention in the field of aquaculture. This study was conducted to investigate the synergistic effect of white spot syndrome virus (WSSV) and Vibrio campbellii on development of disease in specific pathogen-free (SPF) shrimp Litopenaeus vannamei. The juvenile shrimp were first injected with WSSV at a dose of $30 \mathrm{SID}_{50}$ Shrimp $^{-1}\left(\mathrm{SID}_{50}=\right.$ shrimp infectious dose with $50 \%$ endpoint) and $24 \mathrm{~h}$ later with $10^{6}$ colony-forming units (cfu) of $V$. campbellii shrimp $^{-1}$. Controls receiving just one of the pathogens or negative inocula were included. In the treatment with WSSV only, shrimp started to die at 48-108 $\mathrm{h}$ post injection (hpi) and cumulative mortality reached $100 \%$ at $268-336 \mathrm{hpi}$. In the treatment with only V. campbellii injection $\left(10^{6} \mathrm{cfu}\right.$ shrimp $\left.{ }^{-1}\right)$, cumulative mortality reached $16.7 \%$. Shrimp in the dual treatment died very quickly after $V$. campbellii injection and $100 \%$ cumulative mortality was obtained at 72-96 hpi. When WSSV-injected shrimp were given sonicated $V$. campbellii instead of live V. campbellii, no synergistic effect was observed. Density of $V$. campbellii in the haemolymph of co-infected moribund shrimp collected $10 \mathrm{~h}$ after $V$. campbellii injection was significantly higher than in shrimp injected

Received 20 February, 2008; accepted 17 May, 2008. *For Correspondence. E-mail Peter.Bossier@UGent.be; Tel. (+32) 9264 37 53; Fax (+32) 92644193. with $V$. campbellii only $(P<0.01)$. However, there was no difference in WSSV replication between shrimp inoculated with WSSV only compared with dually inoculated ones. This study revealed that prior infection with WSSV enhances the multiplication and disease inducing capacity of $V$. campbellii in shrimp.

\section{Introduction}

Infectious diseases are a major constraint to shrimp aquaculture production in many countries. The rapid increase in cultured areas since the 1980s facilitated spread and outbreaks of a high number of pathogens, viruses in particular. Since its emergence in 1992 (Chou et al., 1995), white spot syndrome virus (WSSV) has been one of the major disease problems in shrimp culture around the world (Lightner, 2003; Rosenberry, 2004; Sanchez-Martinez et al., 2007; Escobedo-Bonilla et al., 2008). In cultured penaeid shrimp, WSSV infections can cause a cumulative mortality up to $100 \%$ within $3-10$ days (Lightner, 1996). Infected shrimp show lethargic behaviour, loss of appetite, reddish discoloration and white spots in the exoskeleton composed of calcified deposits (Chou et al., 1995). WSSV not only infects all shrimp species, but also a wide range of other decapod crustaceans (Lightner et al., 1998). Reports have described both acute and chronic WSSV infections which caused different rates of mortality in shrimp ponds (Sudha et al., 1998) and under experimental conditions (Wang et al., 1999; Rahman et al., 2008).

Species of Vibrio are well known in penaeid shrimp culture as causative agents of vibriosis. This important disease is mainly caused by Vibrio anguillarum, V. alginolyticus, V. parahaemolyticus, V. harveyi, V. penaeicida, $V$. campbellii, both in hatcheries and in grow-out cultures (Lightner, 1988; Lavilla-Pitogo et al., 1990). Infections with luminescent $V$. harveyi strains have been reported to cause major losses in shrimp larviculture in Australia (Pizzutto and Hirst, 1995), South America (Álvarez et al., 1998; Robertson et al., 1998) and Mexico (Vandenberghe et al., 1999). Vibriosis usually occurs during the first month of culture and can cause more than $50 \%$ mortality. So far, it is not clear whether Vibrio spp. are opportunistic or primary pathogens. According to Saulnier and colleagues 


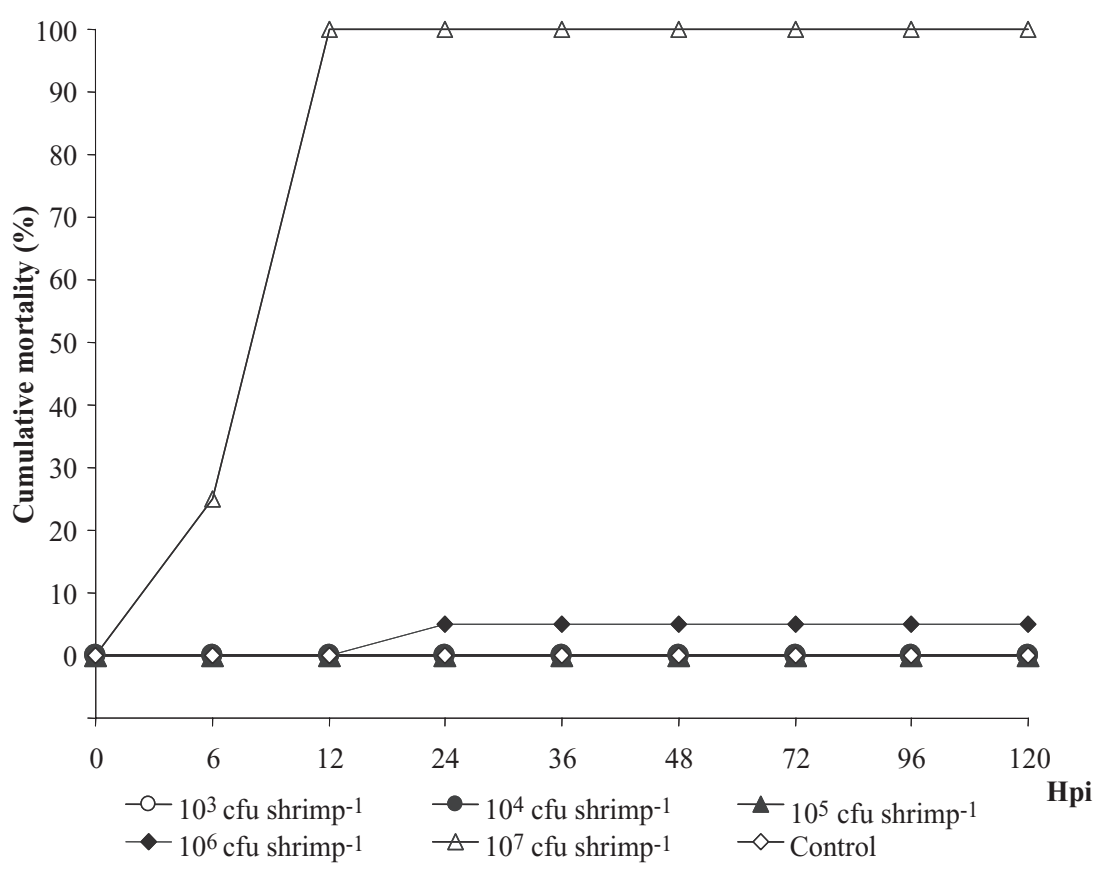

Fig. 1. Cumulative mortality caused by different doses of $V$. campbellii injected in L. vannamei (experiment 1)

(2000a), Vibrio spp. may act as opportunistic agents in secondary infections or be true pathogens. As low number of $V$. penaeicida bacterial cells were shown to produce the disease in Penaeus japonicus and P. stylirostris, Saulnier and colleagues $(2000 \mathrm{~b})$ reported that $V$. penaeicida could act as a primary pathogen. However, pathogenic vibrios were also isolated from apparently healthy penaeid shrimp (Gómez-Gil et al., 1998, Vandenberghe et al., 1998). These observations lead researchers to consider Vibrio spp. are opportunistic pathogens. Horowitz and Horowitz (2001) postulated that if shrimp are not suffering from primary infections, physical damage or stress, their resistance against vibrios is adequate to prevent disease. This idea was further supported by Alday-Sanz and colleagues (2002) who showed that shrimp, when exposed to ammonia prior to immersion challenge with Vibrio, suffered more frequent and earlier pathological changes than shrimp exposed to the bacteria alone.

Only a few cases of polymicrobial disease have been described in shrimp aquaculture. In 2001-2, a retardation of the Penaeus monodon growth rate was noted in shrimp ponds in Thailand. This problem was named Monodon Slow Growth Syndrome. Samples of affected shrimp were screened by histopathology, polymerase chain reaction (PCR) and transmission electron microscopy for a wide range of pathogens. It was discovered that several causative agents were involved. Many shrimp specimens had dual or multiple infections with monodon baculovirus (MBV), heptopancreatic parvovirus (HPV) and infectious hypodermal and haematopoietic necrosis virus (IHHNV) (Chayaburakul et al., 2004). After screening shrimp samples from 18 ponds in India, Umesha and colleagues
(2006) found that the animals in seven ponds showed dual infections with WSSV and MBV and in 10 ponds triple infections with HPV, WSSV and MBV could be found. Selvin and Lipton (2003) demonstrated the presence of a virulent strain of $V$. alginolyticus in shrimp from a pond hit by a WSSV outbreak. Although both pathogens could not be isolated from all sampled shrimp, it was stated that shrimp weakened by WSSV would succumb to a secondary infection by $V$. alginolyticus.

Vibrio is known to be one of the dominant species of bacteria living in shrimp ponds (Hisbi et al., 2000). As a known facultative pathogenic bacterium, it is probable that Vibrio co-infects shrimp with WSSV regularly in the field.

The objective of this study was to reproduce a co-infection of shrimp with WSSV and Vibrio under laboratory conditions using standardized challenge protocols and to investigate the existence of any synergistic effect. More specifically, the question was raised whether a WSSV infection already present in specific pathogen-free (SPF) Litopenaeus vannamei shrimp would allow Vibrio to cause faster and higher mortality rates than the virus or bacteria administered separately.

\section{Results}

Experiment 1: dose effect of $\mathrm{V}$. campbellii on mortality of L. vannamei

In treatments with lower than $10^{6}$ colony-forming units (cfu) of $V$. campbellii shrimp ${ }^{-1}$, no mortality was observed (Fig. 1). When $10^{6} \mathrm{cfu}$ was administered, $5 \%$ cumulative mortality was recorded during the 5-day experimental 


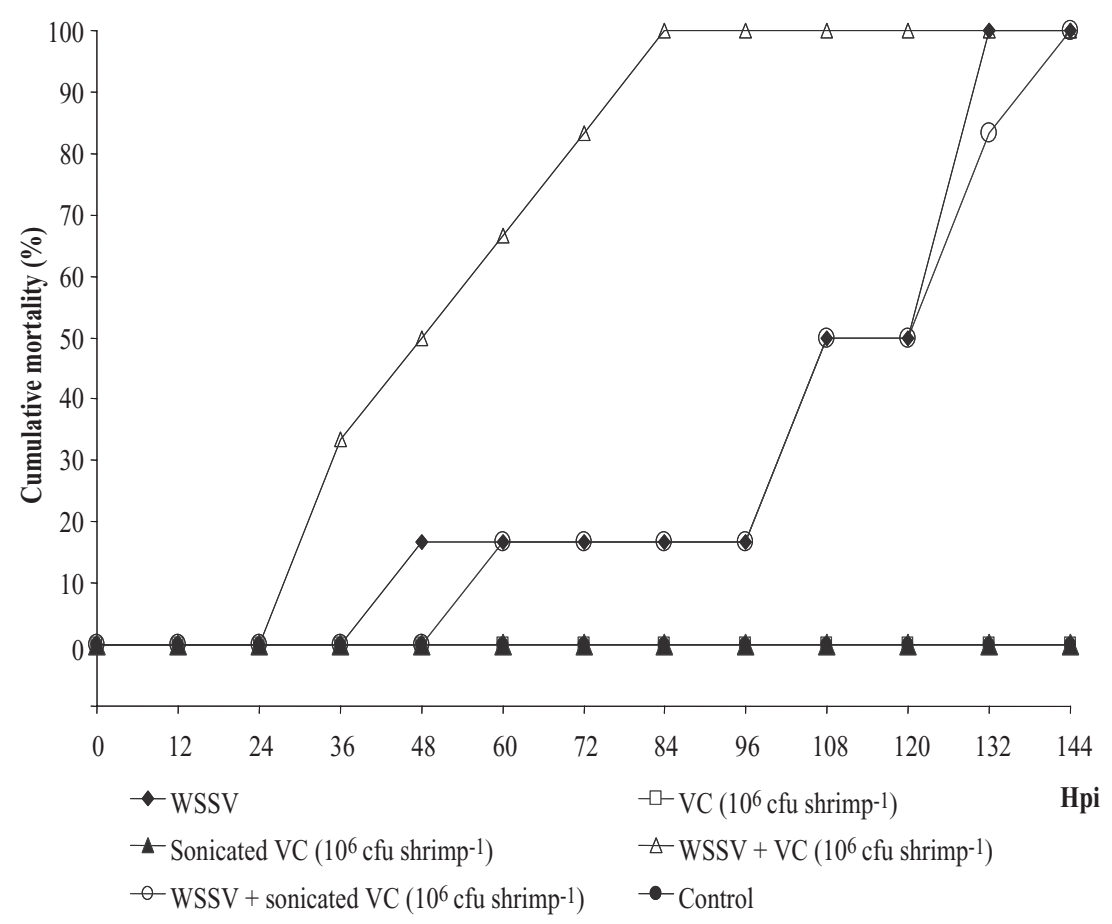

Fig. 2. Cumulative shrimp mortality after challenge with WSSV and sonicated V. campbellii (VC) (experiment 3).

period. On the other hand, shrimp died very quickly after injection with $10^{7}$ cfu of $V$. campbellii and $100 \%$ cumulative mortality was found at $12 \mathrm{~h}$ post injection (hpi). From these results it was concluded that up to a dose of $10^{6}$ cfu shrimp ${ }^{-1}$, V. campbellii on its own was not capable of causing any significant mortality. Therefore, this sublethal dose was chosen for the following co-infection experiments of WSSV and Vibrio.

Experiment 2: effect of sonicated V. campbellii and supernatant from $\mathrm{V}$. campbellii cultures on mortality of L. vannamei

No mortality was observed when shrimp were injected with supernatant, sonicated V. campbellii, Marine Broth (MB) or filtered autoclaved seawater (FASW). It was therefore concluded that no toxic products from V. campbellii which could influence shrimp mortality were present in the inocula.

Experiment 3: effect of sonicated V. campbellii on mortality of WSSV-infected L. vannamei

Mortalities in the treatments with WSSV only and in the dual treatment with WSSV and sonicated V. campbellii evolved in a similar, slow manner (Fig. 2). Cumulative mortality reached $100 \%$ at $132 \mathrm{hpi}$ and $144 \mathrm{hpi}$ respectively. At $84 \mathrm{hpi}$, when cumulative mortality was only $16.7 \%$ in both groups, all shrimp had already died in the dual treatment of WSSV and live $V$. campbellii. These results clearly demonstrated that injection of sonicated
V. campbellii in combination with WSSV did not result in an increase of shrimp mortality.

Experiment 4: co-infection of L. vannamei with WSSV and $\mathrm{V}$. campbellii (first run)

Shrimp injected with WSSV only started to die at $72 \mathrm{hpi}$ and cumulative mortality reached $100 \%$ at $252 \mathrm{hpi}$ (Fig. 3). In the treatment with $10^{6} \mathrm{cfu}$ of Vibrio only, one shrimp died within $12 \mathrm{~h}$ post Vibrio campbellii injection (hpvi) and cumulative mortality reached $16.7 \%$ at the end of the experiment. As in experiment 1, shrimp died quickly after injection with $10^{7}$ cfu of $V$. campbellii. In the treatment with co-infection of WSSV and $V$. campbellii, shrimp started to die at $36 \mathrm{hpi}$ and $66.7 \%$ mortality occurred within $48 \mathrm{hpi}$. These data indicated that the accelerated mortality caused by co-infection as observed in experiment 3 could be reproduced.

Experiment 5: co-infection of L. vannamei with WSSV and V. campbellii (second run)

Shrimp injected with WSSV only started to die at $108 \mathrm{hpi}$ and cumulative mortality reached $100 \%$ at $336 \mathrm{hpi}$ (Fig. 4). Shrimp injected with Vibrio only showed exactly the same mortality rate as in the previous experiment (16.6\%). Animals co-infected by WSSV and V. campbellii died quickly after the challenge with $V$. campbellii, with mortality reaching $66.7 \%$ by $48 \mathrm{hpi}$ and $100 \%$ by $96 \mathrm{hpi}$. Again, the observations showed that the results of the first run of experiment 4 could be reproduced. 


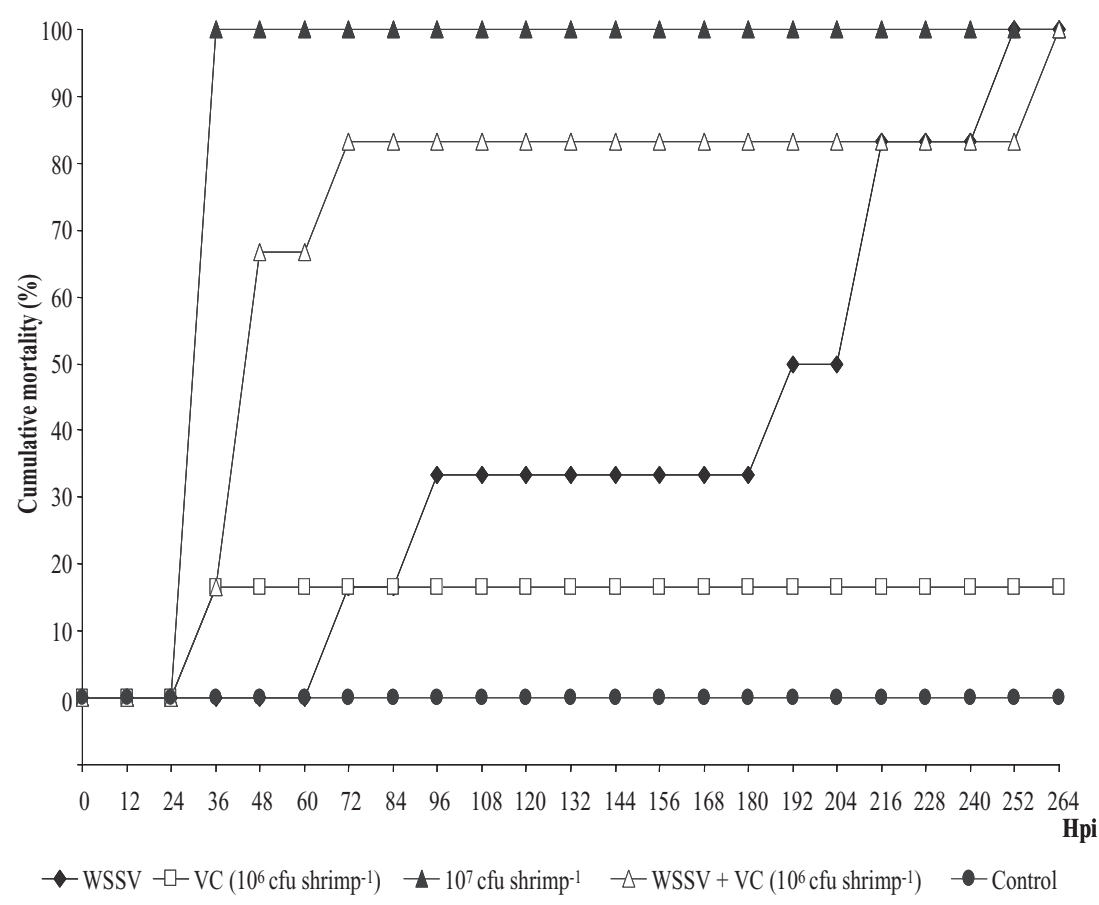

Fig. 3. Cumulative shrimp mortality after challenge with WSSV and $V$. campbellii (first run, experiment 4).

Experiment 5 and 6: quantification of WSSV and $\mathrm{V}$. campbellii in co-infected $\mathrm{L}$. vannamei

In experiment 5, shrimp injected with WSSV only died between 119 and $334 \mathrm{hpi}$. Dually infected animals started to die much faster, between 29 and $96 \mathrm{hpi}$. These moribund shrimp were collected for quantification of WSSV. Gills, stomach and cuticular epithelium and haematopoi- etic tissue were screened for WSSV-infected cells. In the treatment with WSSV only, all shrimp were found to be infected in all organs (Table 1). Overall, fewer WSSVinfected cells were counted in shrimp of the dual treatment and not in all organs.

In experiment 6 , shrimp were collected at $10 \mathrm{hpvi}$ for quantification of WSSV and $V$. campbellii (Table 2). Dual infections did not appear to cause any change in the

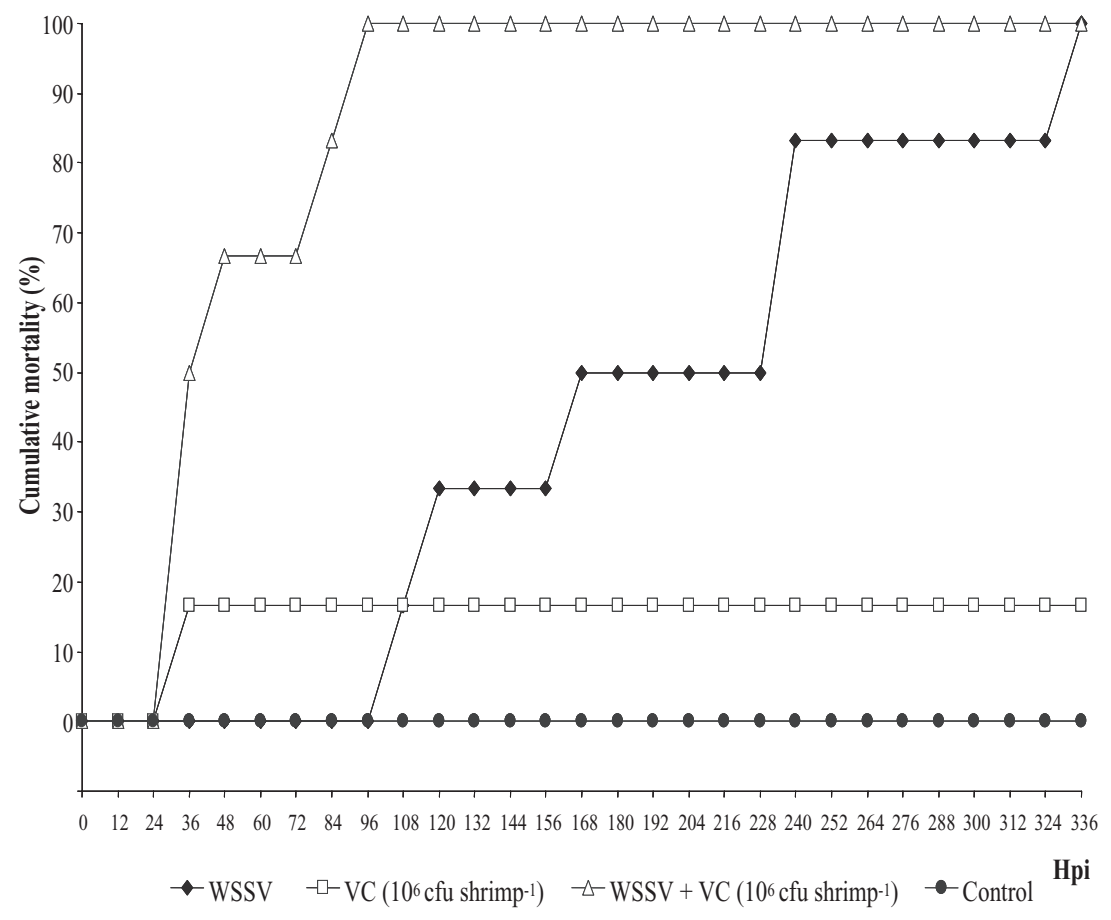

Fig. 4. Cumulative shrimp mortality after challenge with WSSV and V. campbellii (second run, experiment 5).

(C) 2008 The Authors

Journal compilation @ 2008 Society for Applied Microbiology and Blackwell Publishing Ltd, Environmental Microbiology, 10, 2718-2727 
Table 1. Quantification of WSSV-infected cells in gills (G), stomach and cuticular epithelium (SE and CE) and haematopoietic tissue (HP) of shrimp collected at time of death (experiment 5).

\begin{tabular}{|c|c|c|c|c|c|c|}
\hline Treatments & Shrimp & hpi & $\begin{array}{l}\mathrm{G} \\
\text { (cells } \mathrm{mm}^{-2} \text { ) }\end{array}$ & SE (\%) & CE (\%) & $\begin{array}{l}\mathrm{HP} \\
\left(\text { cells } \mathrm{mm}^{-2} \text { ) }\right.\end{array}$ \\
\hline \multirow[t]{6}{*}{ WSSV } & 1 & 119 & 68 & 34 & 19 & 50 \\
\hline & 2 & 119 & 132 & 21 & 17 & 190 \\
\hline & 3 & 170 & 52 & 16 & 19 & 80 \\
\hline & 4 & 232 & 9 & 7 & 8 & 13 \\
\hline & 5 & 237 & 32 & 13 & 24 & 168 \\
\hline & 6 & 334 & 39 & 15 & 19 & 118 \\
\hline \multirow[t]{6}{*}{$W S S V+V C$} & 1 & 29 & 0 & 0 & 0 & 0 \\
\hline & 2 & 35 & 10 & 0.8 & 0.5 & 2.5 \\
\hline & 3 & 37 & 0 & 0 & 0 & 0 \\
\hline & 4 & 41 & 1 & 0 & 0 & 0 \\
\hline & 5 & 83 & 199 & 12.4 & 14.9 & 115 \\
\hline & 6 & 96 & 85 & 23.6 & 18.9 & 30 \\
\hline
\end{tabular}

number of WSSV-infected cells. Positive cells were found in all organs, but no significant difference was found between groups which were administered both pathogens or WSSV alone $(P<0.01)$. The number of $W S S V$-infected cells in haematopoietic tissue (15-568 cells $\mathrm{mm}^{-2}$ ) was higher than that in gills (55-241 cells $\mathrm{mm}^{-2}$ ) and lymphoid organs (3-165 cells $\mathrm{mm}^{-2}$ ) (Table 2 ). In the stomach epithelium, $2-29 \%$ of cells were infected. The number of V. campbellii isolated from bacteria-only-injected shrimp was lower than $100 \mathrm{cfu} \mathrm{ml}^{-1}$. In contrast, a very high density of $V$. campbellii $\left(1.8 \times 10^{6} \mathrm{cfu} \mathrm{ml}^{-1}\right)$ was observed in the haemolymph of shrimp in the dual treatment with WSSV and Vibrio.

\section{Discussion}

The WSSV Viet strain used in the current study caused a rather low mortality rate compared with other strains reported in literature (Lightner, 1996; Sanchez-Martinez et al., 2007; Escobedo-Bonilla et al., 2008). Shrimp injected with only WSSV started to die at 48-108 hpi and cumulative mortality reached $100 \%$ at $132-336 \mathrm{hpi}$. This outcome is not completely in concurrence with previous observations but still within the reported range. Working with the same WSSV strain, injected dose and the same shrimp species but different batch, Rahman and colleagues (2008) documented an onset of mortality at 36-60 hpi and $100 \%$ of cumulative mortality at 204$348 \mathrm{hpi}$. It is interesting to note that the WSSV-induced mortality rate is hardly dependent on the injected dose. Using the same virus batch, Rahman and colleagues (2007a) injected $10000 \operatorname{SID}_{50}\left(\operatorname{SID}_{50}=\right.$ shrimp infectious dose with $50 \%$ endpoint), obtaining $15-25 \%$ cumulative mortality after 36-48 hpi and 100\% mortality after 168$196 \mathrm{hpi}$. All moribund shrimp injected with WSSV only in experiment 5 were positive for WSSV on immunohistochemistry (IHC) staining, confirming that all shrimp died due to the WSSV infection.

The current study supported the hypothesis that V. campbellii used in this study does not cause primary disease in healthy juvenile shrimp, unless high doses were administered. Shrimp injected with $V$. campbellii alone in doses of $10^{5} \mathrm{cfu}$ or lower did not present any signs of mortality. However, the surviving shrimp showed a black spot at the site of $V$. campbellii injection. This observation has also been described by Sarathi and colleagues

Table 2. Quantification of WSSV-infected cells (mean $\pm \mathrm{SD}$ ) and $V$. campbellii (cfu ml-1 of haemolymph) in gills (G), stomach epithelium (SE), lymphoid organ (LO) and haematopoietic tissue (HP) of shrimp collected $10 \mathrm{~h}$ after $V$. campbellii injection (experiment 6 ; shrimp in dual treatment were moribund).

\begin{tabular}{|c|c|c|c|c|c|}
\hline \multirow[b]{2}{*}{ Treatments } & \multicolumn{4}{|c|}{ WSSV-infected cells in organs } & \multirow[b]{2}{*}{ VC $\left(\operatorname{cfu~ml} l^{-1}\right)$} \\
\hline & $\begin{array}{l}\mathrm{G} \\
\text { (cells } \mathrm{mm}^{-2} \text { ) }\end{array}$ & $\begin{array}{l}\mathrm{SE} \\
(\%)\end{array}$ & $\begin{array}{l}\text { LO } \\
\text { (cells mm-2) }\end{array}$ & $\begin{array}{l}\mathrm{HP} \\
\text { (cells } \mathrm{mm}^{-2} \text { ) }\end{array}$ & \\
\hline WSSV & $\begin{array}{l}167 \pm 58^{a} \\
(55-221)\end{array}$ & $\begin{array}{l}17 \pm 10^{a} \\
(2-29)\end{array}$ & $\begin{array}{l}83 \pm 56^{a} \\
(12-138)\end{array}$ & $\begin{array}{l}315 \pm 194^{a} \\
(70-568)\end{array}$ & - \\
\hline VC & - & - & - & - & $\begin{array}{l}43 \pm 61^{a} \\
(0-157)\end{array}$ \\
\hline$W S S V+V C$ & $\begin{array}{l}184 \pm 40^{a} \\
(130-241)\end{array}$ & $\begin{array}{l}14 \pm 5^{a} \\
(4-19)\end{array}$ & $\begin{array}{l}90 \pm 67^{a} \\
(3-165)\end{array}$ & $\begin{array}{l}208 \pm 168^{a} \\
(15-503)\end{array}$ & $\begin{array}{l}183721 \pm 73177^{b} \\
(113000-314600)\end{array}$ \\
\hline
\end{tabular}

Numbers between brackets are minimum and maximum values of six shrimp. Numbers of infected cells in the same tissue or cfu $\mathrm{ml}^{-1}$ with different superscripts were significantly different between the two treatments $(P<0.01)$. 
(2007), who saw haemocytic infiltration and melanization at the injection site upon injections with $V$. alginolyticus in Fenneropenaeus indicus shrimp. In the present study, cumulative mortality reached $16.7 \%$ when shrimp were injected with $10^{6} \mathrm{cfu}$ of $V$. campbellii (Figs 2 and 3 ). Because shrimp died within hours after injection with $10^{7} \mathrm{cfu}$ of $V$. campbellii, it was first considered that shrimp might die as a consequence of toxins produced by the bacteria. However, as no mortality was observed when shrimp were challenged with the supernatant of $V$. campbellii cultures or with sonicated $V$. campbellii, this possibility was ruled out and it was concluded that live bacteria were required to reproduce the disease in shrimp.

In dual treatments of WSSV and $V$. campbellii, a clear acceleration of the mortality of WSSV-infected shrimp was noticed shortly after inoculation with bacteria. Only 1 out of 18 co-infected shrimp survived longer than $96 \mathrm{hpi}$. A similar observation has been published by Pakingking and colleagues (2003). They reported that the mortality rate of flounder fish (Paralichthys olivaceus) increased by secondary infection with Streptococcus iniae or Edwardsiella tarda at 1 week post marine birnavirus (MABV) infection. In the same fish species, Oh and colleagues (2006) also found an increase in mortality of fish co-infected with MABV and $V$. harveyi or E. tarda.

To find out the underlying cause for the rapid mass mortality of the shrimp in the dual treatment, quantification of WSSV in different organs and V. campbellii in the shrimp's haemolymph was performed. It has been established that gills, stomach and cuticular epithelium, haematopoietic tissue and lymphoid organ are major target organs of WSSV replication (Chang et al., 1996). Escobedo-Bonilla and colleagues (2007) and Rahman and colleagues (2008) also selected these organs for enumerating WSSV-infected cells. In the present study, all observed organs of moribund shrimp collected at $10 \mathrm{hpvi}$ (34 hpi) were positive with WSSV. However, the obtained counts were different from the ones obtained by Rahman and colleagues (2008) who reported lower numbers of WSSV-infected cells. This difference might be contributed to the use of shrimp from a different batch and different size. The shrimp in the present study were 4.5 times smaller than the ones used by Rahman and colleagues (2008). Additionally, moribund shrimp were collected in this study instead of euthanized shrimp as mentioned in their report. The most important finding, however, was that the quantification did not reveal any significant difference in the number of WSSV-infected cells between the single and dual treatments. This observation showed that injection of $V$. campbellii did not result in any increase of WSSV replication, thus making it very unlikely that WSSV was responsible for the accelerated mortality. As antibody staining methods for $V$. campbellii are not readily available, re-isolation was chosen as means to quantify
$V$. campbellii in the shrimp's haemolymph. This procedure was facilitated by the use of a rifampycin-resistant strain of $V$. campbellii. Plating of haemolymph samples is one of the few ways to estimate the amount of bacteria replicating inside the body of shrimp and has been used with success in previous studies (Mermound et al., 1998; Van de Braak et al., 2002). In contrast to the viral load, the $V$. campbellii load showed a highly significant difference between single and dual treatments. At $10 \mathrm{hpvi}$, the amount of $V$. campbellii in the haemolymph of moribund shrimp inoculated with both WSSV and V. campbellii was more than $10^{3}$ times higher than that in shrimp that received bacteria only. Apparently, low densities of bacteria could be eliminated quickly by shrimp that were not coping with a WSSV infection. Van de Braak and colleagues (2002) also recorded that the concentration of live bacteria in haemolymph of shrimp decreased by $97 \%$ within $2 \mathrm{~h}$ after injection. This was attributed to the host's defence system, more specifically, the clearing mechanism of the shrimp's haemocytes.

Sizeable individual variations in numbers of WSSVinfected cells and $V$. campbellii in the haemolymph at certain time points were observed in dual and single treatments. Individual variations in the load of WSSV in shrimp were reported earlier (Tan et al., 2001; Durand and Lightner, 2002) and can be explained by differences in viral replication, defence response of the host and/or susceptibility among individuals of the same species. Differences in bacterial density between individual shrimp can also reflect the variable health status of shrimp. It appears that stronger shrimp can eliminate bacteria very fast, while weaker ones do it slowly or cannot resist to the bacteria and finally die.

To explain the findings of the current study, it is postulated that the bacterial clearing capacity of shrimp can be severely undermined by a WSSV infection, even in the early stages of the viral disease. Consequently, $V$. campbellii is allowed to multiply unchecked in the shrimp's body, rapidly leading to death. Previous research has documented negative effects, both of WSSV and of $V$. campbellii, on vital physiological processes. Jiravanichpaisal and colleagues (2006) reported that granular haemocytes of WSSV-infected crayfish had lost their capacity to induce melanization. WSSV inhibits the proPO system upstream of phenoloxidase or simply consumes the native substrate for the enzyme so that no activity can occur. Scholnick and colleagues (2006) found that $L$. vannamei injected with $V$. campbellii decreased oxygen uptake by $27 \%$ after $4 \mathrm{~h}$. This phenomenon persisted $24 \mathrm{~h}$ after Vibrio injection. The inhibition of melanization due to WSSV might be directly linked with improved dissemination of $V$. campbellii inside shrimp. The combination with a reduced oxygen level caused by the Vibrio can result in an acute threat to the survival of shrimp. 
In conclusion, an injection with live $V$. campbellii $24 \mathrm{~h}$ after a WSSV injection clearly accelerated mortality in juvenile SPF L. vannamei shrimp. Such accelerated mortality was not observed when shrimp were injected with very high dose of WSSV (Rahman et al., 2007a). The presence of $V$. campbellii did not result in any increase of WSSV replication, but the density of $V$. campbellii in haemolymph increased spectacularly, resulting in much faster mortality of dually inoculated shrimp. The combination of these findings strongly argues for a synergistic effect in which a low non-lethal WSSV load allows for a rapid Vibrio multiplication. All research performed on Vibrio infection of shrimp can no longer deny this phenomenon, as viral load at the start of the experiment has a dramatic effect on the outcome. The use of SPF shrimp is paramount, or the quantification of the viral load should be taken into account.

With their wide distribution, it is probable that co-infections of WSSV and Vibrio can occur regularly in the field. However, detailed research is required to elucidate the importance and the exact mechanism of polymicrobial infections in shrimp ponds.

\section{Experimental procedures}

\section{Viral and bacterial stocks}

Viral stock. A Vietnamese WSSV isolate was used in this study. This isolate was studied before and was shown to be significantly less virulent than two other isolates from Thailand (Rahman et al., 2007a,b). The original WSSV isolate from naturally infected $P$. monodon was passaged once into crayfish (Cherax quadricarinatus). Crayfish gill suspension containing WSSV was received from Research Institute for Aquaculture No2, Vietnam. The isolate was amplified in SPF $L$. vannamei juveniles. The virus stock was titrated in vivo by intramuscular route and the virus titre was $10^{5,8} \mathrm{SID}_{50} \mathrm{ml}^{-1}$ as determined by indirect immunofluorescence (IIF) and onestep PCR (Escobedo-Bonilla et al., 2005). A dose of $30 \mathrm{SID}_{50}$ was prepared in a volume of $50 \mu$ by diluting the stock with phosphate-buffered saline (PBS). As a control inoculum (mock), PBS alone was used.

Bacterial stock. Vibrio campbellii (LMG21363) was obtained from the Laboratory of Microbiology (Ghent University, Belgium). The strain, previously stored in $20 \%$ glycerol at $-80^{\circ} \mathrm{C}$, was aseptically inoculated in Marine Agar (MA). The plates were incubated for $24 \mathrm{~h}$. Single colonies were subsequently transferred and grown in MB 2216 (Difco Laboratories, USA) by incubation overnight $\left(28^{\circ} \mathrm{C}, 150\right.$ r.p.m.). The culture was then transferred to centrifugation tubes and centrifuged at $2200 \mathrm{~g}$ for $15 \mathrm{~min}$. The supernatant was discarded and pellets were washed twice and finally re-suspended in FASW. The bacterial densities were determined spectrophotometrically at an optical density of $550 \mathrm{~nm}$ assuming that an optical density of 1.0 corresponds to $1.2 \times 10^{9}$ cells $\mathrm{ml}^{-1}$, the McFarland standard (Bio Merieux, France). A bacterial dose of $10^{6} \mathrm{cfu} 100 \mathrm{\mu l}^{-1}$ was prepared. As a control, FASW was used.

\section{Experimental animals and conditions}

Specific pathogen-free L. vannamei of the Kona-Hawaii (USA) strain (Wyban et al., 1992) were used in this study. Shrimp were imported from Molokai Sea Farms, Hawaii (USA). Animals were certified to be free of WSSV, IHHNV, MBV, HPV, Taura syndrome virus (TSV), Yellow head virus (YHV) and Gill-associated virus (GAV), as well as other pathogens (fungi, protozoa) as verified by PCR and histopathology. Batches of shrimp arrived at the Laboratory of Aquaculture and Artemia Reference Center (ARC), Ghent University, as post-larvae $\left(\mathrm{PL}_{8-12}\right)$. They were kept in a recirculation system at a water temperature of $28-29^{\circ} \mathrm{C}, 34 \mathrm{mg} \mathrm{l}^{-1}$ salinity and $\mathrm{pH}$ of $7.8-8.1$. During the first week, the animals were fed twice daily with Artemia nauplii. After 1 week their diet was shifted to A2 monodon high-performance shrimp feed (2.2 mm fraction, INVE Aquaculture NV, Belgium). The feeding ratio was $2.5 \%$ of the mean body weight (MBW) day $^{-1}$. In this study, shrimp were taken randomly from the population and gradually acclimatized to a salinity of $15 \mathrm{~g} \mathrm{l}^{-1}$ over 4 days. Acclimatized shrimp were transported to the facilities of the Laboratory of Virology, Faculty of Veterinary Medicine, Ghent University, where the infection experiments were performed under biosafety conditions. One day before and during the entire period after the inoculation, shrimp were housed individually in covered $10 \mathrm{I}$ aquaria, filled with artificial seawater prepared with distilled water at a salinity of $15 \mathrm{~g} \mathrm{I}^{-1}$, provided with constant aeration and maintained at $27 \pm 1^{\circ} \mathrm{C}$ by air heaters. Feeding was skipped for $24 \mathrm{~h}$ prior to the injection, and resumed 6 hpi. During the experiments, shrimp were fed three pellets of feed every $12 \mathrm{~h}$.

\section{Rifampycin-resistant V. campbellii}

Rifampycin-resistant (RR) V. campbellii was produced as follows: a colony picked from MA plates was cultured for $24 \mathrm{~h}$ in $25 \mathrm{ml}$ of MB in $100 \mathrm{ml}$ erlenmeyer. After incubation, $50 \mu \mathrm{l}$ of the culture was taken by micropipette and transferred to $25 \mathrm{ml}$ of fresh MB containing $0.5 \mathrm{mg} \mathrm{l}^{-1}$ rifampycin. The culture was incubated for $24 \mathrm{~h}$ at $28^{\circ} \mathrm{C}$. The growth of bacteria was indicated by turbidity of the culture. In the following days, further subcultures were made in $M B$, increasing the rifampycin concentration gradually from 1, 2, 4, 8, 16, 32, 64 to finally $100 \mathrm{mg} \mathrm{l}^{-1}$. When bacteria cultures were growing well in the final concentration of rifampycin $\left(100 \mathrm{mg} \mathrm{l}^{-1}\right)$, they were inoculated on MA plates containing $100 \mathrm{mg} \mathrm{l}^{-1}$ rifampycin for obtaining single colonies. The stock was stored in $20 \%$ glycerol at $-80^{\circ} \mathrm{C}$ for long-term storage.

\section{IHC and quantification of WSSV-infected cells}

Shrimp samples were collected and fixed in Davidson's fixative for $36 \mathrm{~h}$ and kept in 50\% ethanol afterwards. Samples were processed as described by Bell and Lightner (1988). Paraffin-embedded tissue sections were cut at $5 \mathrm{~mm}$ and placed onto Silane-coated slides (A3648, Sigma-Aldrich). Sections were deparaffinized and rehydrated. The endogenous peroxidase was blocked by incubating the slides for $30 \mathrm{~min}$ at room temperature in a solution of $1 \%$ sodium azide and $0.02 \%$ hydrogen peroxidase in Tris buffer $\mathrm{pH} 7.4$. 
Sections were incubated for $1 \mathrm{~h}$ at $37^{\circ} \mathrm{C}$ with $2 \mu \mathrm{g} \mathrm{ml}{ }^{-1}$ of monoclonal antibody 8B7 raised against WSSV envelope protein VP28 (Poulos et al., 2001). Sections were washed in Tris buffer $\left(\mathrm{pH} \mathrm{7.6)}\right.$ and incubated for $1 \mathrm{~h}$ at $37^{\circ} \mathrm{C}$ with a 1:200 dilution of biotinylated sheep anti-mouse IgG antibodies (RPN1001, Amersham Biosciences). Afterwards they were washed, incubated for $30 \mathrm{~min}$ at room temperature with 1:200 dilution of streptavidine-biotinylated horseradish peroxidase complex (RPN1051 Amersham Biosciences) and washed again. Colour was developed with $0.01 \%$ of 3, 3'-diaminobenzidine (D8001 Sigma-Aldrich). Sections were counterstained with Gill's haemaluin and washed in water, dehydrated and mounted. WSSV-infected cells were counted using light microscopy (Leica DM RBE) at a 400x magnification in five fields in gills and lymphoid organs and in two to three fields in haematopoietic tissue. These counts were converted to the number of WSSV-infected cell $\mathrm{mm}^{-2}$. Both WSSV-infected and uninfected cells in stomach epithelium and cuticular epithelium were counted in five fields and the average percentage (\%) of infected cells was calculated.

\section{Enumeration of $\mathrm{V}$. campbellii}

Rifampycin-resistant $V$. campbellii were enumerated on $\mathrm{MA}+100 \mathrm{mg} \mathrm{l}^{-1}$ rifampycin (MAR). Haemolymph was obtained from the ventral part of the haemocoel of the second abdominal segment, using a 25-gauge needle and a $1 \mathrm{ml}$ syringe rinsed with cold modified Alsever's solution [AS; $19.3 \mathrm{mM} \mathrm{Na}$ citrate, $239.8 \mathrm{mM} \mathrm{NaCl}, 182.5 \mathrm{mM}$ glucose, $6.2 \mathrm{mM}$ EDTA (ethylene diaminetetra-acetic acid); $\mathrm{pH}$ 7.2] as an anticoagulant (Rodriguez et al., 1995). Directly after sampling, haemolymph was serially diluted in FASW and plated on MAR. The plates were incubated at $28^{\circ} \mathrm{C}$ for $24 \mathrm{~h}$. As RR V. campbellii are luminous bacteria, all colonies were checked for luminescence before counting to ensure that no contamination had occurred during the sampling procedure.

\section{Destruction of bacterial cells by sonicator}

A bath sonicator and glass beads were used for destruction of the bacterial cells. For this purpose, V. campbellii were up-scaled for $12 \mathrm{~h}$ in an erlenmeyer containing $25 \mathrm{ml}$ of $\mathrm{MB}$. Harvesting of bacteria was performed by centrifugation for $15 \mathrm{~min}$ at $2200 \mathrm{~g}$. The cells were washed twice and finally re-suspended in FASW. Six millilitres of bacterial suspension with a density of $10^{7} \mathrm{cfu} \mathrm{ml}^{-1}$ was transferred to a $50 \mathrm{ml}$ falcon tube containing glass beads and was vortexed for $3 \mathrm{~min}$. Then, it was kept in $-80^{\circ} \mathrm{C}$ for $20 \mathrm{~min}$. Subsequently, it was thawed in sonicator for $3 \mathrm{~min}$, vortexed for $3 \mathrm{~min}$, sonicated for $6 \mathrm{~min}$ and was placed back in $-80^{\circ} \mathrm{C}$ for $20 \mathrm{~min}$. The freeze and thaw cycle was repeated for six times. After each cycle, samples were collected and plated on MA to check whether the bacteria had been killed by the procedure. The supernatant was prepared by culturing of $V$. campbellii in MB for $24 \mathrm{~h}$. The cultures were then transferred to the falcon tube and centrifuged for $15 \mathrm{~min}$ at $2200 \mathrm{~g}$. The supernatant was collected and filtered through $0.2 \mu \mathrm{m}$ filter paper.

\section{Experimental design}

Experiment 1: dose effect of V. campbellii on mortality of L. vannamei. The aim of this experiment was to find the highest possible dose of $V$. campbellii which does not cause significant mortalities in L. vannamei. This sublethal dose was used for the co-infection experiments. Juvenile shrimp $(\mathrm{MBW}=12.47 \pm 0.89 \mathrm{~g})$ were injected $(100 \mu \mathrm{l})$ with different doses of $V$. campbellii containing $10^{3}, 10^{4}, 10^{5}, 10^{6}$ or $10^{7} \mathrm{cfu}$ per shrimp respectively. As control inoculum, shrimp were injected with the same volume of FASW. Each treatment was performed with two replicates of 10 shrimp and the experiment lasted 5 days. Every $6 \mathrm{~h}$, shrimp were monitored for disease symptoms and moribund/dead shrimp were collected.

Experiment 2: effect of sonicated V. campbellii and supernatant from V. campbellii cultures on mortality of $\mathrm{L}$. vannamei. This experiment was conducted to test whether toxic products produced by $V$. campbellii, both extra- or intracellular, could be responsible for shrimp death. The experiment was set up with four different treatments. Shrimp (MBW $=1.1 \pm 0.17 \mathrm{~g}$ ) were injected either with supernatant or sonicated $V$. campbellii or with MB or FASW as a control. Each treatment was performed with three replicates of 10 shrimp. Every $6 \mathrm{~h}$, they were monitored for disease symptoms and moribund/dead shrimp were removed. The experiment was terminated after 5 days.

Experiment 3: effect of sonicated $\mathrm{V}$. campbellii on mortality of WSSV-infected L. vannamei. This experiment tested the effect of sonicated $V$. campbellii on the mortality of WSSVinfected shrimp. The experiment was set up with six treatments. At $0 \mathrm{hpi}$, groups of six shrimp (MBW $=$ $5.17 \pm 0.9 \mathrm{~g}$ ) were either injected with WSSV at a dose of $30 \mathrm{SID}_{50}$ shrimp $^{-1}$ (treatment 1, 4 and 5) or mock inoculated (treatment 2, 3 and 6). At $24 \mathrm{hpi}$, shrimp were either injected with $10^{6}$ cfu of $V$. campbellii (treatment 2 and 4), negative inocula (treatment 1 and 6) or sonicated $V$. campbellii (treatment 3 and 5). After each injection procedure, shrimp were placed in their individual $10 \mathrm{I}$ aquarium. Every $12 \mathrm{~h}$, they were monitored for disease symptoms and moribund/dead shrimp were collected. Every 5 days, $75 \%$ of water was replaced with new seawater ( $15 \mathrm{~g} \mathrm{l}^{-1}$ salinity) to minimize ammonia build-up. The experiment was terminated when mortality reached $100 \%$ in the WSSV only group.

Experiment 4: co-infection of L. vannamei with WSSV and V. campbellii (first run). The experiment was set up with five treatments to investigate the synergistic effect of WSSV and $V$. campbellii on the mortality of $L$. vannamei. At $0 \mathrm{hpi}$, groups of six shrimp (MBW $=16.8 \pm 2.1 \mathrm{~g}$ ) were either injected with WSSV at a dose of 30 SID $_{50}$ shrimp $^{-1}$ (treatment 1 and 3) or mock inoculated (treatment 2, 4 and 5). After $24 \mathrm{~h}$, all shrimp were either injected with $10^{6} \mathrm{cfu}$ (treatment 2 and 3) or $10^{7} \mathrm{cfu}$ of $V$. campbellii (treatment 5) or mock inoculated (treatment 1 and 4). After each injection procedure, shrimp were placed in their individual $10 \mathrm{I}$ aquarium. Every $12 \mathrm{~h}$, they were monitored for disease symptoms and moribund/dead shrimp were removed. Temperature and ammonium were checked daily. Every 5 days, $75 \%$ of water was replaced with new seawater (15 $\mathrm{g} \mathrm{I}^{-1}$ salinity) to minimize ammonia build-up. 
Experiment 5: co-infection of L. vannamei with WSSV and V. campbellii (second run) and quantification of WSSV. In this experiment, we aimed at repeating experiment 4 , and at the same time collect samples that would allow for the quantification of WSSV. The experiment was identical to experiment 4, except that the positive control group was omitted. Moribund shrimp (MBW $=21.5 \pm 2.4 \mathrm{~g}$ ) were collected at different time points for quantification of WSSV-infected cells by IHC.

Experiment 6: quantification of WSSV and V. campbellii in co-infected L. vannamei. This experiment was set up to collect moribund shrimp for quantification of WSSV and V. campbellii. The experimental design was identical to experiment 5 but shrimp were injected with $10^{5} \mathrm{cfu}$ of V. campbellii instead of $10^{6} \mathrm{cfu}$ as mentioned in previous experiments. This dose was chosen as it did not cause any mortality when injected alone but could lead to a very clear acceleration of mortality in co-infections with WSSV. In this experiment, RR $V$. campbellii were used to avoid contamination during re-isolation. A test confirmed that the selection process had not altered the virulence of this strain. Each treatment started with 12 shrimp (MBW $=4.35 \pm 0.72 \mathrm{~g})$. Ten hours post $V$. campbellii injection, six shrimp were collected from each treatment for quantification of the two pathogens.

\section{Statistical analysis}

Differences between treatments were evaluated by performing $t$-test analysis using statistical analysis software SPSS (version 13.0 for Windows). Values in percentages (WSSV-infected cells in stomach epithelium) were ArcSintransformed to satisfy normal distribution.

\section{Acknowledgements}

This study was supported by a PhD scholarship of the Vietnamese Overseas Scholarship Program-322 Project. The second author received a scholarship from the Institute for the promotion of Innovation by Science and Technology in Flanders (IWT) (Belgium). Special thanks go to the director of the Research Institute for Aquaculture No2 in Vietnam, Dr Nguyen Van Hao, and the staff of the Artemia Reference Center (Ghent, Belgium) for their kind support and guidance.

\section{References}

Alday-Sanz, V., Roque, A., and Turnbull, J.F. (2002) Clearing mechanisms of Vibrio vulnificus biotype I in the black tiger shrimp Penaeus monodon. Dis Aquat Organ 48: 91-99.

Álvarez, J.D., Austin, B., Álvarez, A.M., and Reyes, H. (1998) Vibrio harveyi: a pathogen of penaeid shrimps and fish in Venezuela. J Fish Dis 21: 313-316.

Bell, T.A., and Lightner, D.V. (1988) A Handbook of Normal Penaeid Shrimp Histology. Baton Rough, LA, USA: The World Aquaculture Society.

Chang, P.S., Lo, C.F., Wang, Y.C., and Kou, G.H. (1996) Identification of white spot syndrome associated baculovirus (WSBV) target organs in the shrimp Penaeus monodon by in situ hybridization. Dis Aquat Organ 27: 131-139.
Chayaburakul, K., Nash, G., Pratanpipat, P., Sriurairatana, S., and Withyachumnarnkul, B. (2004) Multiple pathogens found in growth-retarded black tiger shrimp Penaeus monodon cultivated in Thailand. Dis Aquat Organ 60: 89-96.

Chou, H.Y., Huang, C.Y., Wang, C.H., Chiang, H.C., and Lo, C.F. (1995) Pathogenicity of a baculovirus infection causing white spot syndrome in cultured penaeid shrimp in Taiwan. Dis Aquat Organ 23: 165-173.

Durand, S.V., and Lightner, D.V. (2002) Quantitative real time PCR for the measurement of white spot syndrome virus in shrimp. J Fish Dis 25: 381-389.

Escobedo-Bonilla, C.M., Wille, M., Alday-Sanz, V., Sorgeloos, P., Pensaert, M.B., and Nauwynck, H.J. (2005) In vivo titration of white spot syndrome virus (WSSV) in SPF Litopenaeus vannamei by intramuscular and oral routes. Dis Aquat Organ 66: 163-170.

Escobedo-Bonilla, C.M., Wille, M., Alday-Sanz, V., Sorgeloos, P., Pensaert, M.B., and Nauwynck, H.J. (2007) Pathogenesis of a Thai strain of white spot syndrome virus (WSSV) in juvenile, specific pathogen-free Litopenaeus vannamei. Dis Aquat Organ 74: 85-94.

Escobedo-Bonilla, C.M., Alday-Sanz, V., Wille, M., Sorgeloos, P., Pensaert, M.B., and Nauwynck, H.J. (2008) A review on the morphology, molecular characterization, morphogenesis and pathogenesis of white spot syndrome virus. J Fish Dis 31: 1-18.

Gómez-Gil, B., Tron-Mayén, L., Roque, A., Turnbull, J.F., Inglis, V., and Guerra-Flores, A.L. (1998) Species of Vibrio isolated from hepatopancreas, haemolymph and digestive tract of a population of healthy juvenile Penaeus vannamei. Aquaculture 163: 1-9.

Hisbi, D., Vandenberghe, J., Robles, R., Verdonck, L., Swings, J., and Sorgeloos, P. (2000) Characterisation of Vibrio and related bacteria associated with shrimp Penaeus monodon larvae in Indonesia. Asian Fish Sci 13: 57-64.

Horowitz, A., and Horowitz, S. (2001) Disease control in shrimp aquaculture from a microbial ecology perspective. In The New Wave, Proceedings of the Special Session on Sustainable Shrimp Culture, Aquaculture 2001. Browdy, C.L., and Jory, D.E. (eds). Baton Rouge, LA, USA: The World Aquaculture Society, pp. 199-218.

Jiravanichpaisal, P., Sricharoen, S., Söderhäll, I., and Söderhäll, K. (2006) White spot syndrome virus (WSSV) interaction with crayfish haemocytes. Fish Shellfish Immunol 20: 718-727.

Lavilla-Pitogo, C.R.M., Baticados, C.L., Cruz Lacierda, E.R., and De La Peña, L.D. (1990) Occurrence of luminous bacterial disease of Penaeus monodon larvae in the Philippines. Aquaculture 91: 1-13.

Lightner, D.V. (1988) Vibrio disease in penaeid shrimp. In Disease Diagnosis and Control in North American Marine Aquaculture, 2nd edn. Sinderman, C.J., and Lightner, D.V. (eds). Amsterdam: Elsevier, pp. 42-47.

Lightner, D.V. (1996) A Handbook of Pathology and Diagnostic Procedures for Diseases of Penaeid Shrimp. Baton Rouge, LA, USA: World Aquaculture Society.

Lightner, D.V. (2003) The Penaeid Shrimp Viral Pandemics due to IHHNV, WSSV, TSV and YHV: Current Status in the Americas, Vol. 1. World Aquaculture Society Meeting, 
Salvador, Brazil, Book of Abstracts, Baton Rouge, LA, USA: World Aquaculture Society, p. 418.

Lightner, D.V., Hasson, K.W., White, B.L., and Redman, R.M. (1998) Experimental infection of western hemisphere Penaeid shrimp with Asian white spot syndrome virus and Asian yellow head virus. J Aquat Anim Health 10: 271-281.

Mermound, I., Costa, R., Ferré, O., Goarant, C., and Haffner, P. (1998) 'Syndrome 93' in New Caledonian outdoor rearing ponds of Penaeus stylirostris: history and description of three major outbreaks. Aquaculture 164: 323-335.

Oh, M.J., Kim, W.S., Kitamura, S.I., Lee, H.K., Son, B.W., Jung, T.S., and Jung, S.J. (2006) Change of pathogenicity in Olive flounder Paralichthys olivaceus by co-infection of Vibrio harveyi, Edwardsiella tarda and marine birnavirus. Aquaculture 257: 156-160.

Pakingking, J.R., Takano, R., Nishizawa, T., Mori, K., Lida, Y., Arimoto, M., and Muroga, K. (2003) Experimental coinfection with aquabirnavirus and viral hemorrhagic septicemia virus (VHSV), Edwardsiella tarda or Streptococcus iniae in Japanese Flounder Paralichthys olivaceus. Fish Pathol 38: 15-21.

Pizzutto, M., and Hirst, R.G. (1995) Classification of isolates of Vibrio harveyi virulent to Penaeus monodon larvae by protein profile analysis and M13 DNA fingerprinting. Dis Aquat Organ 21: 61-68.

Poulos, B.T., Pantoja, C.R., Bradley-Dunlop, D., Aguila, J., and Lightner, D.V. (2001) Development and application of monoclonal antibodies for the detection of white spot syndrome virus of penaeid shrimp. Dis Aquat Organ 47: 13-23.

Rahman, M.M., Corteel, M., Dantas-Lima, J.J., Wille, M., Alday-Sanz, V., Pensaert, M.B., et al. (2007a) Impact of daily fluctuations of optimum $\left(27^{\circ} \mathrm{C}\right)$ and high water temperature $\left(33^{\circ} \mathrm{C}\right)$ on Penaeus vannamei juveniles infected with white spot syndrome virus (WSSV). Aquaculture 269: 107-113.

Rahman, M.M., Corteel, M., Wille, M., Alday-Sanz, V., Pensaert, M.B., Sorgeloos, P., and Nauwynck, H.J. (2007b) The effect of raising water temperature to $33^{\circ} \mathrm{C}$ in Penaeus vannamei juveniles at different stages of infection with white spot syndrome virus (WSSV). Aquaculture 272: 240245.

Rahman, M.M., Corteel, M., Escobedo-Bonilla, C.M., Wille, M., Alday-Sanz, V., Pensaert, M.B., et al. (2008) Virulence of white spot syndrome virus (WSSV) isolates may be correlated with the degree of replication in gills of Penaeus vannamei juveniles. Dis Aquat Organ 79 (3): 191-198.

Robertson, P.A.W., Calderon, J., Carrera, L., Stark, J.R., Zherdmant, M., and Austin, B. (1998) Experimental Vibrio harveyi infections in Penaeus vannamei larvae. Dis Aquat Organ 32: 151-155.

Rodriguez, J., Boulo, V., Mialhe, E., and Bachère, E. (1995) Characterisation of shrimp haemocytes and plasma components by monoclonal antibodies. J Cell Sci 108: 10431050.

Rosenberry, B. (2004) World shrimp farming 2004. In Shrimp News International. Rosenberry, B. (ed.). San Diego, CA, USA.

Sanchez-Martinez, J.G., Aguirre-Guzman, G., and MejiaRuiz, H. (2007) White spot syndrome virus in cultured shrimp: a review. Aquacult Res 38: 1339-1354.
Sarathi, M., Ishaq Ahmed, V.P., Venkatesan, C., Balasubramanian, G., Prabavathy, J., and Sahul Hameed, A.S. (2007) Comparative study on immune response of Fenneropenaeus indicus to Vibrio alginolyticus and white spot syndrome virus. Aquaculture 271: 8-20.

Saulnier, D., Haffner, P., Goarant, C., Levy, P., and Ansquer, D. (2000a) Experimental infection models for shrimp vibriosis studies: a review. Aquaculture 191: 133-144.

Saulnier, D., Avarre, J.C., Le Moullac, G., Ansquer, D., Levy, P., and Vonau, V. (2000b) Evidence that Vibrio penaeicida is a putative etiological agent of syndrome'93 in New Caledonia and development of a rapid and sensitive PCR assay for its detection in shrimp and sea water. Dis Aquat Org 40: 109-115.

Scholnick, D.A., Burnett, K.G., and Burnett, L.E. (2006) Impact of exposure to bacteria on metabolism in the Penaeid shrimp Litopenaeus vannamei. Biol Bull 211: 44-49.

Selvin, J.L., and Lipton, A.P. (2003) Vibrio alginolyticus associated with white spot disease of Penaeus monodon. Dis Aquat Organ 57: 147-150.

Sudha, P.M., Mohan, C.V., Shankar, K.M., and Hegde, A. (1998) Relationship between White Spot Syndrome Virus infection and clinical manifestation in Indian cultured penaeid shrimp. Aquaculture 167: 95-101.

Tan, L.T., Soon, S., Lee, K.L., Shariff, M., Hassan, M.D., and Omar, A.R. (2001) Quantitative analysis of an experimental white spot syndrome virus (WSSV) infection in Penaeus monodon Fabricus using competitive polymerase chain reaction. J Fish Dis 24: 315-323.

Umesha, K.R., Dass, B.K.M., Naik, B.M., Venugopal, M.N., Karunasagar, I., and Karunasagar, I. (2006) High prevalence of dual and triple viral infections in black tiger shrimp ponds in India. Aquaculture 258: 91-96.

Van de Braak, C.B.T., Botterblom, M.H.A., Taverne, N., van Muiswinkel, W.B., Rombout, J.H.W.M., and van der Knaap, W.P.W. (2002) The roles of haemocytes and the lymphoid organ in the clearance of injected Vibrio bacteria in Penaeus monodon shrimp. Fish Shellfish Immunol 13: 293-309.

Vandenberghe, J., Li, Y., Verdonck, L., Li, J., Sorgeloos, P., Xu, H.S., and Swings, J. (1998) Vibrio associated with Penaeus chinensis (Crustacea: Decapoda) larvae in Chinese shrimp hatcheries. Aquaculture 169: 121-132.

Vandenberghe, J., Verdonck, L., Robles Arozarena, R., Rivera, G., Bolland, A., Balladares, M., et al. (1999) Vibrios associated with Litopenaeus vannamei larvae, postlarvae, broodstock, and hatchery probionts. Appl Environ Microbiol 65: 2592-2597.

Wang, Q., White, B.L., Redman, R.M., and Lightner, D.V. (1999) Per os challenge of Litopenaeus vannamei postlarvae and Farfantepenaeus duorarum juveniles with six geographic isolates of white spot syndrome virus. Aquaculture 170: 179-194.

Wyban, J.A., Swingle, J.S., Sweeney, J.N., and Pruder, G.D. (1992) Development and commercial performance of high health shrimp using specific pathogen free (SPF) broodstock Penaeus vannamei. In Proceedings of the Special Session on Shrimp Farming. Wyban, J.A. (ed.). Baton Rouge, LA, USA: World Aquaculture Society, pp. 254266. 